\section{ECONOMICS}

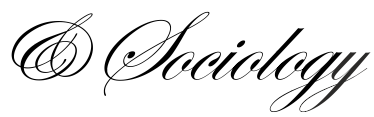

Francisia S. S. E. Seda

Department of Sociology,

Universitas Indonesia,

Depok, Indonesia

E-mail:ery.seda09@ui.ac.id

ORCID 0000-0003-2060-6504

\section{Lugina Setyawati}

Department of Sociology,

Universitas Indonesia,

Depok, Indonesia

E-mail:

lugina.setyawati@gmail.com

\section{Yosef Hilarius Timu Pera \\ Department of Sociology, \\ Universitas Indonesia, \\ Depok, Indonesia \\ E-mail:yoseph.hilarius@ui.ac.id}

\section{Muhammad R. Damm}

Department of Language and Art,

Universitas Indraprasta,

Jakarta, Indonesia

E-mail:

mubammaddamm@gmail.com

\section{Kevin Nobel}

Department of Sociology,

Universitas Indonesia,

Depok, Indonesia

E-mail:kevinnobel93@gmail.com
Seda, F. S. S. E., Setyawati, L., Pera, Y. H. T., Damm, M. R., \& Nobel, K. (2020). Social exclusion, religiouscapital, and the quality of life: Multiple case studies of Indonesia and Thailand. Economics and Sociology, 13(4), 107-124.

doi:10.14254/2071-789X.2020/13-4/7

\title{
SOCIAL EXCLUSION, RELIGIOUS CAPITAL, AND THE QUALITY OF LIFE: MULTIPLE CASE STUDIES OF INDONESIA AND THAILAND
}

ABSTRACT. By analyzing the case of Indonesia and Thailand, this study fills the gap in quantitative studies on the importance of social factors at the community level. This research emphasized the relation of social exclusion and religious capital to quality of life, whereas previous researches generally used individual and economic factors as the basis. To elaborate the correlation between the three concepts above, this research used quantitative survey method with heads of households aged 18-64 years old as the population. The sample was drawn proportionally by means of multistage cluster sampling based on social class, religion and urban and rural sampling. For research in Indonesia, in-depth interviews were also conducted to obtain supporting data. The results show that social access and religious capital as social factors at the community level have different impacts on the quality of life in Indonesia and Thailand. Social access has more impact in Thailand, while it is religious capital in Indonesia. Theoretically, in heterogeneous society, religious capital plays important roles because it is primarily used to access resources. Trust and networking which are developed in a community will contribute to individuals' subjective meaning in accordance with their quality of life.

Received: January, 2020

1st Revision: August, 2020

Accepted: December, 2020

DOI: $10.14254 / 2071-$

789X.2020/13-4/7 


\begin{abstract}
JEL Classification: Z12, L31 Keywords: Indonesia, Thailand, quality of life, religious capital, social exclusion
\end{abstract}

\title{
Introduction
}

This study compares Indonesia and Thailand, two countries in the Southeast Asia (SEA) region, to describe the relations between social exclusion, religious capital, and the quality of life. These two countries are selected for several reasons, including different status and condition of quality of life between them, as well as the diversity of socio-cultural and economic backgrounds within their population.

In terms of economic and social welfare, Thailand represents the country that has emerged from a low-income country back in the 1960s to become a high-income country in the 2010s (Guillen-Royo, Velazco, Camfield, 2011). Rapid economic growth and development contribute to its HDI (Human Development Index) score. Accordingly, by 2015, Thailand has been already categorized as a country with high HDI (UNDP, 2016). Meanwhile, Indonesia, which has been independent for more than 70 years, represents a country that is still struggling to improve the welfare of its nation. Based on the HDI score, Indonesia is categorized as a middle rank country, see Table 1 .

Table 1. Human Development Index and Happiness Index of the SEA Countries

\begin{tabular}{lcc}
\hline Country & HDI (2015) & Happiness Index (2016) \\
\hline Singapore & 0.925 (Very High HDI - rank 5) & 6.572 (Rank 26) \\
\hline Brunei & 0.865 (Very High HDI - rank 30) & not available \\
\hline Malaysia & 0.789 (High HDI - rank 59) & 6.084 (Rank 42) \\
\hline Thailand & 0.740 (High HDI -rank 87) & 6.424 (Rank 32) \\
\hline Indonesia & 0.689 (Medium HDI-rank 113) & 5.262 (Rank 81) \\
\hline Vietnam & 0.683 (Medium HDI-rank 115) & 5.074 (Rank 94) \\
\hline Philippines & 0.682 (Medium HDI-rank 116) & 5.430 (Rank 72) \\
\hline Timor Leste & 0.605 (Medium - 133) & NA \\
\hline Laos & 0.856 (Medium - 138) & 4.876 (Rank 102) \\
\hline Cambodia & 0.563 (Medium - 143) & 4.168 (Rank 129) \\
\hline Myanmar & 0.556 (Medium - 145) & 4.545 (Rank 114) \\
\hline
\end{tabular}

Source: UNDP (2016) and Helliwell, Layard \& Sachs (2017)

Numerous studies on social well-being discuss the quality of life. Generally speaking, the quality of life represents conditions of both objective and subjective well-being, on individual and community level. The score of the Human Development Index (HDI) represents the objective indicators of well-being, whereas the Happiness Index represents the subjective indicators of well-being. In this regard, country's economic and social policies are believed to contribute to both indices.

Several studies have explained how the concept of economic (Bucur, 2017; Kireenko \& Nevzorova, 2015; Haq \& Zia, 2013) and individual (Zhang, Hui, Lam, Lau, Cheung \& Mok, 2013) factors affect the quality of life. However, there is only a limited number of studies which stressed on the social factors at the community level. Therefore, our research tries to fill this gap. The novelty and the contribution of this research is in exploring the importance of social factors at the community level to explain the conditions behind the quality of life, which have not been addressed in previous studies. Even if there were previous studies that discussed a similar topic, the link between social factors at the community level and the quality of life is mostly studied in qualitative terms. 


\section{Literature review}

HDI is an objective indicator of social wellbeing that also indicates quality of life. In addition to HDI as an objective indicator, the table above presents Happiness Index as the subjective indicator of social wellbeing. It shows that Thailand's Happiness Index is much higher than Indonesia's. Based on the level of HDI and Happiness Index, it is reasonable to assume that the quality of life of Thailand is better than Indonesia. The data of both countries also illustrate a positive relation between objective and subjective social wellbeing in which the country with high HDI tends to have high Happiness Index.

In terms of demographic profile, Indonesia and Thailand are culturally diverse countries indicated by the variety of religious affiliations held by its people. Nevertheless, Theravada Buddhism is the religion of vast majority in Thailand (94.50\% of its population, based on 2015 statistics), where its adherents spread throughout the country. Muslims are the second largest (4.29\% of its population) and concentrated mainly in Southern Thailand, while the adherents of Christianity, Hinduism, Sikhism, and Confucianism are minority groups with relatively insignificant numbers. According to the 2015 census, the composition of Thailand's population based on religion is shown in the following table 2:

Table 2. Population based on Religion in Thailand (2010-2016)

\begin{tabular}{lcccc}
\hline Religion & Number $(2010)^{\mathrm{I}}$ & Percentage & Number $(2016)$ & Percentage \\
\hline Buddhism & $61,746,429$ & $93.58 \%$ & $63,620,298$ & $94.50 \%$ \\
\hline Islam & $3,259,340$ & $4.94 \%$ & $2,892,311$ & $4.29 \%$ \\
\hline Christianity & 789,376 & $1.20 \%$ & 787,589 & $1.17 \%$ \\
\hline Hinduism & 41,808 & $0.06 \%$ & 22,110 & $0.03 \%$ \\
\hline No religion & 46.122 & $0.07 \%$ & 2,925 & $0.005 \%$ \\
\hline Other religions & 70.742 & $0.11 \%$ & 1,583 & $0.002 \%$ \\
\hline Sikhism & 11,124 & $0.02 \%$ & 1,030 & $0.001 \%$ \\
\hline Confucianism & 16,718 & $0.02 \%$ & 716 & $0.001 \%$ \\
\hline
\end{tabular}

Source: web.nso.go.th/en/survey/2015-2016-executive summary

Similarly, Indonesian population is predominantly comprised by one religious group. Based on 2010 national census, the vast majority of Indonesian population is Muslim (87.18\% of its population) who lives mostly in the islands of Java and Sumatra. According to the Indonesia Central Bureau of Statistics (2011: 11), in every province, except Bali, East Nusa Tenggara, West Kalimantan, North Sulawesi, Maluku, West Papua, and Papua, Islam is embraced by at least $60 \%$ of the population. These religious backgrounds of their population contribute to the identity and cultural characteristic of Indonesia and Thailand, shown on Table 3.

Table 3. Number and Percentage of Population based on Religion (2010)

\begin{tabular}{lcc}
\hline Religion & Number & Percentage \\
\hline Islam & $207,176,162$ & 87,18 \\
\hline Protestant & $16,528,513$ & 6,96 \\
\hline Catholic & $6,907,873$ & 2,91 \\
\hline Hinduism & $4,012,116$ & 1,69 \\
\hline Buddhism & $1,703,254$ & 0,72 \\
\hline Confucianism & 117,091 & 0,05 \\
\hline Others & 299,617 & 0,13 \\
\hline No answered/No respond & 139,582 & 0,06 \\
\hline Not questioned & 757,118 & 0,32 \\
\hline \multicolumn{2}{l}{} \\
\hline Total & $237,641,326$ & 100 \\
\hline
\end{tabular}

Source: BPS (2011: 10) 
Literatures on Southeast Asia countries show that religion is an integral part of the public sphere and even infiltrates government affairs (Hefner, 2015; Dubus, 2016). Dubus (2016) discussed how the Thai monarchy has declared Theravada Buddhism as the country's official religion and as cultural heritage that should be cared. Meanwhile, Islam as a religion of the vast majority in Indonesia, coloring social activities in society as well as state policy, although the government has never established Indonesia as an Islamic state (Hefner, 2015). Consequently, either in Indonesia or Thailand, religious identity, beside of economic status, has been the important factor for people to access various resources. In this context, some studies show how the minority and marginalized groups experienced social exclusion.

This study considers religious identity as an important factor which contributes to the quality of life. The status of social wellbeing is related to social capital that works at the community level. The context of society, however, affects how the social capital works in the community. In a culturally diverse society, religious identity needs to be considered in the discussion of social capital (Bowman, Denson \& Park, 2015). This article uses the terminology of religious capital as a dimension of social capital that focuses on trust in religious groups, cooperation among members of denominations and spirituality that play a role in facilitating individuals and groups in their lives.

This paper aims to understand the relation between social exclusion, religious capital, and quality of life by comparing the condition of social well-being between Indonesia and Thailand based on a survey conducted in both countries in 2017. The survey examines three (3) dimensions of social wellbeing, namely personal, relational, and societal dimension. This study discussing on religious capital as an intervening variable to social access and quality of life.

\section{Theoretical framework}

The concept of social exclusion in general refers to a lack of participation in social support, social networks, and access to a wide range of goods and services (Lee \& Shrum, 2012). In general, there are four elements in social exclusion:

1. Multiple Deprivation: not only financially poor and unemployed, but also includes not being able to interact socially and not having a community.

2. Relativity: shows the people who were excluded from the community at a specific time and location.

3. Agency: where people or agents experience exclusion both voluntary and involuntary.

4. Dynamics: where people can be unemployed, experience financial pressure, or a reduced opportunity of becoming more prosperous in the future.

The operational definition of social exclusion includes five forces that encourage the process of social exclusion, namely, poverty and low income, lack of access to the labor market, weakness or lack of social support and social networks, effect of neighborhood and living environment, and disconnected from services. The five forces exclude individuals or groups of people. Poverty can be classified as absolute poverty and relative poverty. Lack of access to the labor market is associated with formal employment. Lack of social support and social networks are defined as the absence of a large family or close friends who can provide support. The neighborhood refers to the immediate surroundings. Disconnected from the services refer to basic services such as transport, health, education, electricity, and clean water. Peace (2001) mentions 15 kind of social exclusion form in society, such as: social marginalisation, new poverty, democratic legal/political exclusion, nonmaterial disadvantage, exclusion from the "minimal acceptable way of life", cultural exclusion (including race and gender), exclusion from family and the community, exclusion from the walfare state, long-term poverty, exclusion 
from mainstream political and economic life, poverty, state of deprivation, detachment from work relations, economic exclusion, and exclusion from the labour market.

Vertical dimension based social exclusion refers to social exclusion based on social stratification in a particular society. These bases for exclusion include poverty and low income and their implications on lack of access and lack of opportunities. Horizontal dimension based social exclusion refers to social cleavages present in a specific society, including different groupings based on primordial associations such as ethnic groups, religious groups, ideological groups, etc., and its implications on discrimination and lack of access and lack of opportunities.

Conceptually, the secondary data analysis is still limited to show empirically the link between the social exclusion process and the conditions of social wellbeing which can be felt and can be experienced by individuals, groups, communities, and society. Further secondary data analysis is needed to prove empirically the relation between the process of social exclusion and the conditions of social wellbeing in a community within a certain time period; also the nature and extent of the relations. Even though further secondary data analysis is needed to prove empirically and conclusively the relations between the process of social exclusion and the conditions of social wellbeing in a community, but previous researches on wellbeing has shown that there is an overlapping between society, social wellbeing, and social quality (Hearan Koo, et.al, 2016). Specifically, the definition of Social Wellbeing is viewed as a combination of the perception of individual life conditions, their quality of relationship with others, and the conditions of society they live in (Hearan Koo, et.al, 2016). There are three dimensions: personal, relational, and societal wellbeing. Personal wellbeing is at individual level (micro level), relational wellbeing is at group level (micro level and meso level), and societal wellbeing is at structural level (macro level). Koo et al (2016) explain that the concept of social well-being is closely related to the experience and behavior at interpersonal and societal level. According to them, by adding the word "social" in the concept of well-being, we focus on the nature of individual relationships in everyday life and their interaction with the institutional and normative aspects of society. Helliwell (2003) as cited by Koo et al (2016) showed that the degree of connectedness has a positive effect on individuals' subjective well-being.

Social quality is important to Social Wellbeing because it forms the perceived conditions of society where people interact with each other. Social Quality indicates that Society requires four conditional factors; socio economic security, social cohesion, social inclusion, and social empowerment. In this Social Quality framework, people have their own specific life experiences which constitutes Social Wellbeing (Hearan Koo, et.al, 2016).

Religious capital as a concept has been evolving and developing through many works and studies ever since. Berger and Hefner (2003) understand spiritual capital as 'the power, influence, knowledge and dispositions created by participation in a particular religious tradition.' In accordance with Bourdieu's, this definition of spiritual capital understands it as a resource, but emphasizes its nature as a resource that originates from social life (participation). In its 2003 study, Metanexus Institute used 'spiritual capital' with the working definition of it as 'the effects of religious and spiritual practices, beliefs, networks and institutions that have a measurable impact on individuals, communities and societies.' In addition, we need to understand religious capital as a kind of social capital; and by social capital, the definition offered by Robert Putnam seems to be appropriate. As social capital refers to connections among individuals-social networks, and the norms of reciprocity and trustworthiness that arise from them' (Putnam, 2000), then religious capital refers to social networks based on religious atribute.

Some studies show the connection between religious activities and life satisfaction. Roemer (2010) refers to studies conducted in the context of American society that show social participation in the religious activities have positive relation to integration and social support that in turn contribute to life satisfaction. He, subsequently, used these findings to support his 
study on 'Religion and Subjective Wellbeing in Japan'. Other study also demonstrates the roles of religious capital toward the aspirations for the future among African American communities. The African American communities are characterized by a strong religious orientation and activities, demonstrated by the central role of the church as religious institution. As well, Boon and Farnsworth (2011) underlines the ways social capital of a group impeded other groups from the access to social resources. He associates the social capital as a constraining factor with diversity as an important factor in the society indicated by different religious affiliation. The main point of these studies is that religious identity and activities have become an element of social capital that contributes to the life satisfaction as the subjective wellbeing indicator. This argument primarily works on diverse societies. Different from the American society and the West European countries, where the religious affairs are positioned in private sphere, in the Asian societies, particularly in Southeast Asian countries, religious affairs are part of private and public spheres (Candland, 2000; Roemer, 2010; Hoon, 2016; Goh \& Van der Veer, 2016; Van der Veer, 2009).

The theoretical assumption is that the higher the social access, with the higher of religious capital, will increase the higher social quality of life (means the higher the relational well-being). The reverse is the theoretical assumption that the lesser social access, with the lesser religious capital, will decrease social quality of life (means the lower relational wellbeing).

\section{Methodological approach}

The main method used for this research is the quantitative-survey method. The use of the survey method to study social exclusion variables and religious capital is a relatively new thing and is an advantage in this study. A number of studies on religious capital and social exclusion use more qualitative methods and data. The large number of samples and dataset is also an added value for this study in proving arguments regarding the relationship between social exclusion as an independent variable, and religious capital as an intermediate variable.

This study utilizes the data set gathered from the social well-being survey done by the International Consortium for Social Well-being Studies lead by Senshu University Japan, that was held in the seven (7) participating consortium countries, which are Japan, South Korea, Taiwan, Indonesia, Vietnam, Thailand, and the Philippines.

The study population was household heads aged 18 - 64 years, which is the economically productive age. This is intended to prove the argument that economic conditions are not always the main determinant of social wellbeing, as well as to test other factors such as religious values, local wisdom, and so on. The study sample was drawn by multistage cluster sampling to capture all characteristics related to social wellbeing and quality of life such as the proportion of the sample based on social class, the population living in urban and rural areas, the proportion based on religion, and social class.

The Indonesian survey was conducted in 2017 and covered several provinces: Jakarta, Banten, West Java, Yogyakarta, and Bali with a total of 1250 samples, taken in a multistage random sampling method to represent the population condition in Indonesia. Based on majority and minority religions, social class, as well as urban and rural populations. Meanwhile, the study in Thailand was conducted in 2016 by taking a proportionate 995 samples from all provinces by also taking sample quotas based on social class and religion. In several previous studies, the quality of life in rural and urban areas has relevance to the quality of life conditions. Meanwhile, religious variation (majority-minority) is closely related to the religious capital variable.

For Indonesian data, we also collected qualitative data by conducting in-depth interviews with some informants in survey locations in the provinces of Banten, Yogyakarta, 
and Bali to deepening our understanding about religious capital. Banten was chose since it has Muslim majority, Yogyakarta was chosen since it has relatively balance composition between Muslim and non-Muslim population, whereas Bali was chosen since it is predominated by Hinduism. Informants for in-depth interviews were chose purposively to represent social groups whose social wellbeing is in the ends of the spectrum, namely high and low, and is in the moderation. They were also chosen purposively to represent different religious groups.

Data from questionnaire processed by indexation (combining the scores) and recategorization in order to make data interpretation and inference easier. To examine the correlation between independent and dependent variables, we apply bivariate and multivariate analyses using regression analysis. This analysis aims to examine whether religious capital can strengthen the relation between social access and the quality of life.

\section{Conducting research and results}

\subsection{Description of quality of life, social access, and religious capital condition in Indonesia and Thailand}

\subsubsection{Social Exclusion (Social Access)}

Degree of Access $(n=2231)$

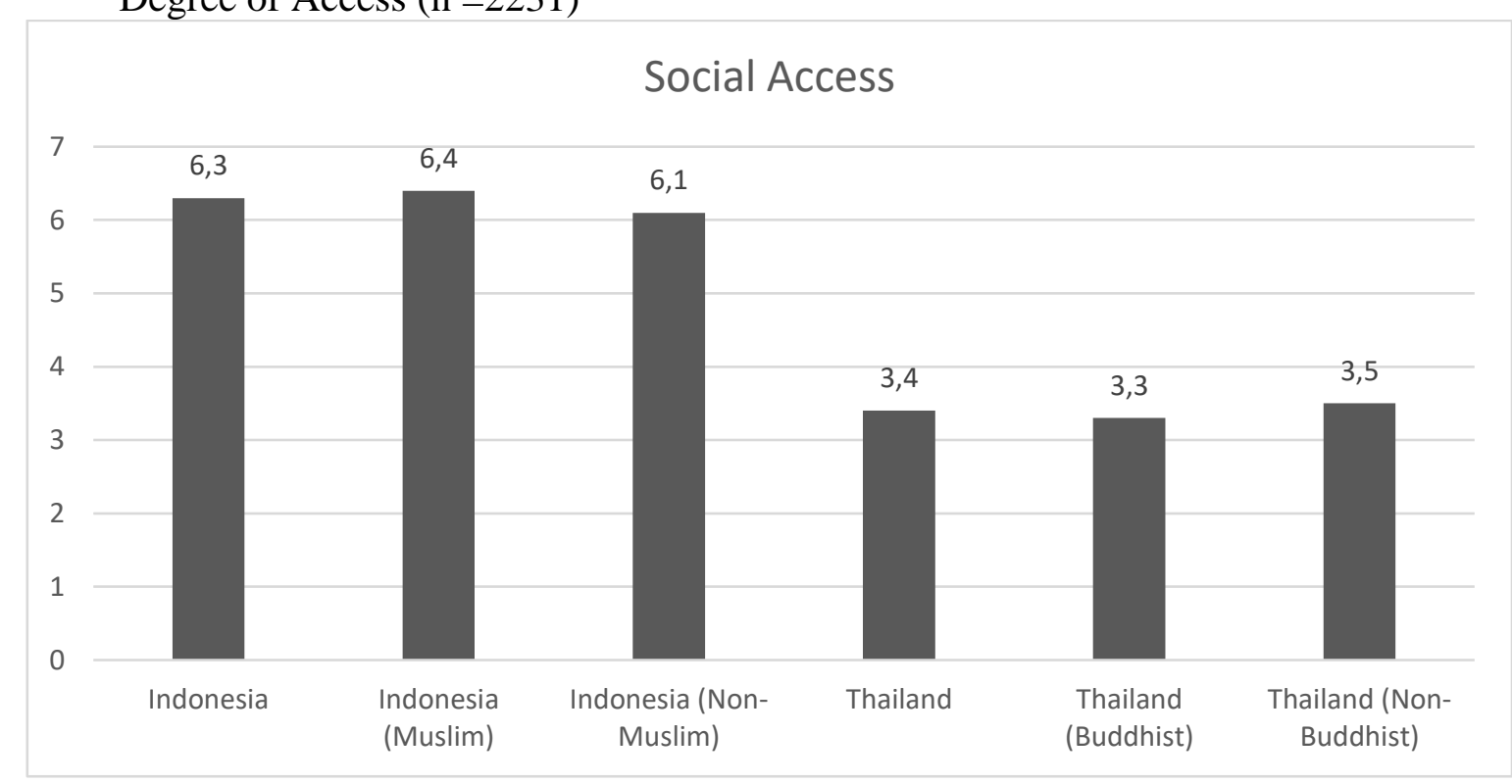

Graph 1. Social Exclusion (Social Access) in Indonesia and Thailand

Source: own data

Degree of access represents an overview concerning the relation between identity and the experiences of being treated fairly by society as a whole. The components of identity in this survey include gender, age, educational background, occupation, income, assets, family background, race, ethnicity, religion and traditional beliefs. The diagram above shows both average score of degree of access and score of degree of access based on religious group in Indonesia and Thailand. In average, Indonesia has a higher score of degree of access than Thailand. This indicates that according to Indonesian respondents, identity contributes to degree of access more significantly compared to Thai respondents. The gap between Indonesia's score and Thailand's is quite significant, 6.4 compared to 3.4 respectively. Having review the contribution of each component towards the degree of access, the result shows that religion is 
the highest component of identity that contributes to the degree of access, with score of 7.4 (see the elaborated scores of each component of identity in the attachment: matrix of degree of access). On the contrary, the survey results in Thailand demonstrate that religion is the least component of identity that contributes to the degree of access as shown by the score of 1.9.

\subsubsection{Quality of life (social wellbeing with personal, relational, and societal dimension)}

The quality of life measurement is developed based on three (3) dimensions of social wellbeing i.e. personal, relational, and societal. In the survey, each dimension is measured on the basis of several questions (see second column in the table of Quality of Life based on Religion (Indonesia \& Thailand) in the attachment).

The following chart depicts the results of SWB survey concerning the quality of life in general and the quality of life based on religious identity in Indonesia and Thailand. (Graph 2)

$(\mathrm{n}=2238)$

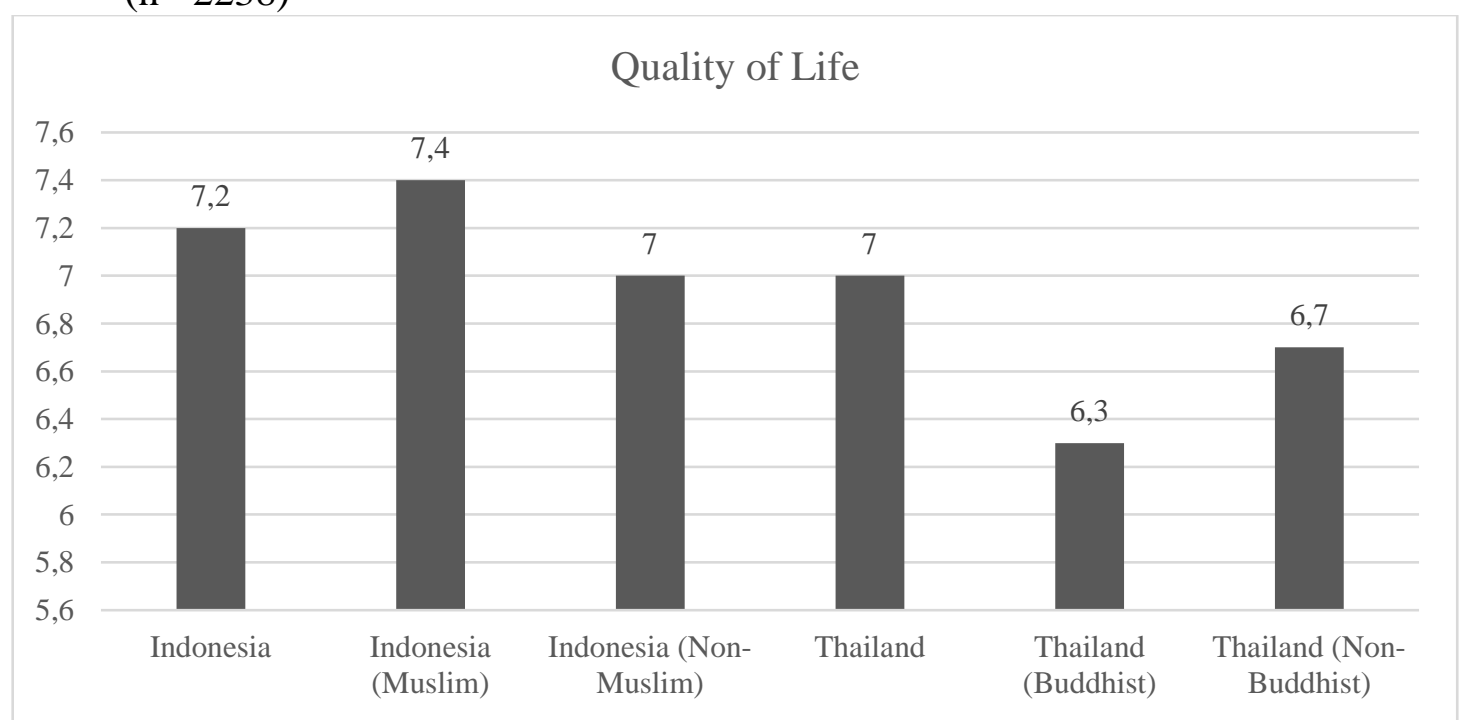

Graph 2. Quality of Life Based on Religious Identity

Source: own data

The SWB survey results in both countries show that the average score of the quality of life among Indonesian respondents is slightly higher than the average score of Thai respondents. This is indicated by score of 7.2 for Indonesia and score of 7.0 for Thailand. The scores of personal and relational dimensions among Indonesian respondents are higher compared to Thai respondents. Indonesia's score of personal dimension is 8.03, while Thailand's is 7.6. Indonesia's score of relational dimension is 6.9, while Thailand's is 6.1. But, Thailand has a higher score for societal dimension in which Indonesia's score is 6.8, while Thailand's is 7.1. These findings indicate that in the Indonesian context, the respondents are more satisfied with personal and relational than societal wellbeing. Meanwhile, in the context of Thailand, the respondents are more satisfied with societal wellbeing.

For more specific findings based on religious affiliation, the research results demonstrate that in Indonesia, the respondents that affiliated with religion held by the majority (the Muslims) have higher level of the quality of life (7.2) than those who are not (the nonMuslims: 7.0). However, the SWB survey in Thailand shows different result. In this country, there is no difference between respondents who are affiliated with religion held by the majority (the Buddhist) and those who are not. The findings indicate that the Indonesian respondents 
consider religious identity and religious orientation as important factors contribute to the quality of life.

\subsubsection{Religious capital}

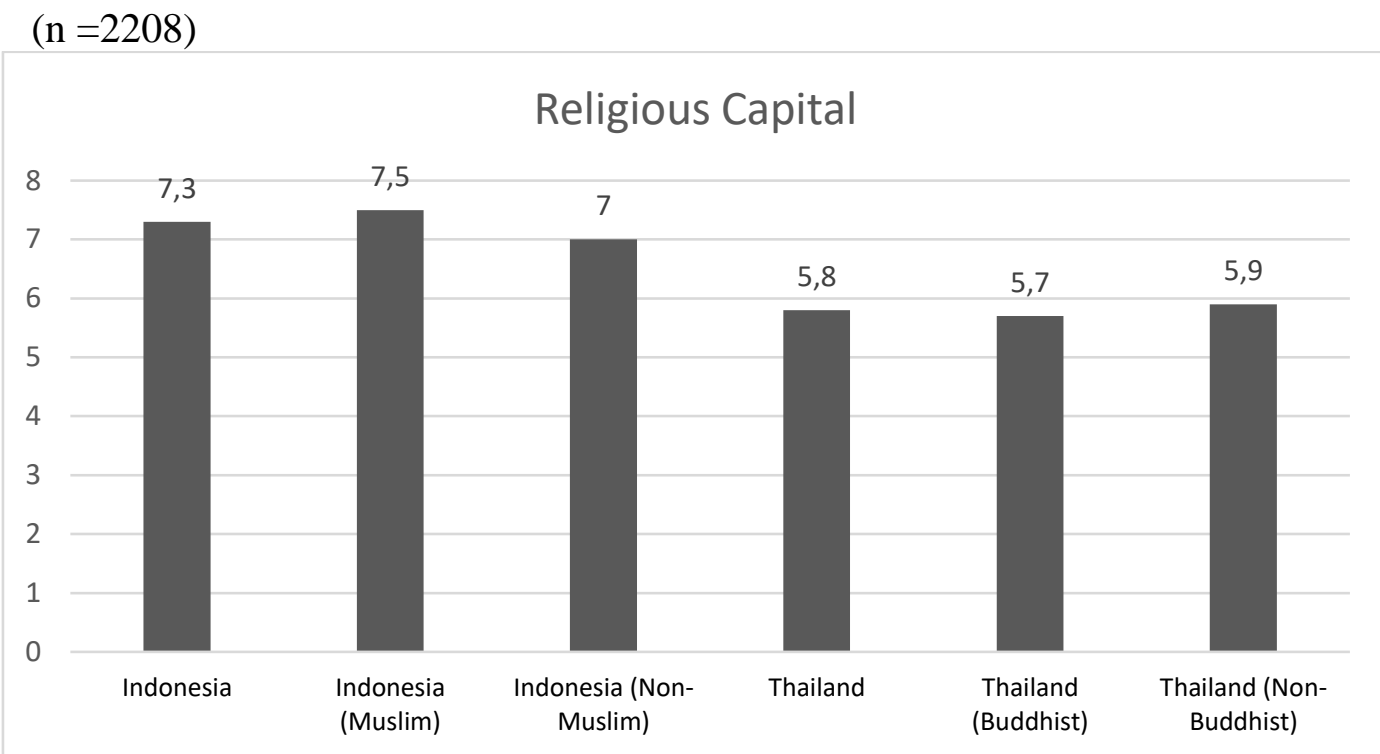

Graph 3. Religious Capital in Indonesia and Thailand

Source: own data

The figure above outlines the scores of religious capital in Indonesia and Thailand based on the results of the SWB survey. The survey data is also presented here by categorizing the respondents into two groups, which are those who are affiliated to the religion held by majority and those who are not. The result shows that the level of religious capital in Indonesia is higher than in Thailand. This is appropriate to both the average score and the scores based on religious group in each country. Based on the SWB survey, average score of religious capital in Indonesia is 7.3, while the average score of religious capital in Thailand is 5.8. Thus, Indonesian respondents regard religious capital as a more important factor in facilitating their lives compared to respondents in Thailand. This level of religious capital is indicated by respondents' views on the fairness of treatment from the community regarding their religious identity, their trust to religious leaders, the benefits they gained from their religious identity, and how they rely on religious institutions and religious groups in tackling their daily problems and in handling accident/disasters. Based on elaborated data that measures the score of religious capital, the survey findings show that the religious identity implicates to fair/unfair treatment among Indonesian respondents (score 7.3). Meanwhile, among respondents of SWB survey in Thailand, the result indicates that the implication of religious identity on fair/unfair treatment from the society is lower (score 1.9). Another interesting finding is that among Indonesian respondents, community leaders have important roles as it is indicated by its score of 8.2. The score of importance of religious leader in Thailand is lower, i.e. 5.8.

The result also demonstrates that the group of those who are affiliated with majority (Muslim in Indonesia and Buddhist in Thailand) has higher score compared to non-Muslim (in Indonesia) and non-Buddhist (in Thailand). The score gap, however, is not significant. 


\subsection{Multivariate Analysis: Do Religious Capital Matters?}

\subsubsection{Indonesia Social Access, Religious Capital, Quality of Life: Multiregression Analysis}

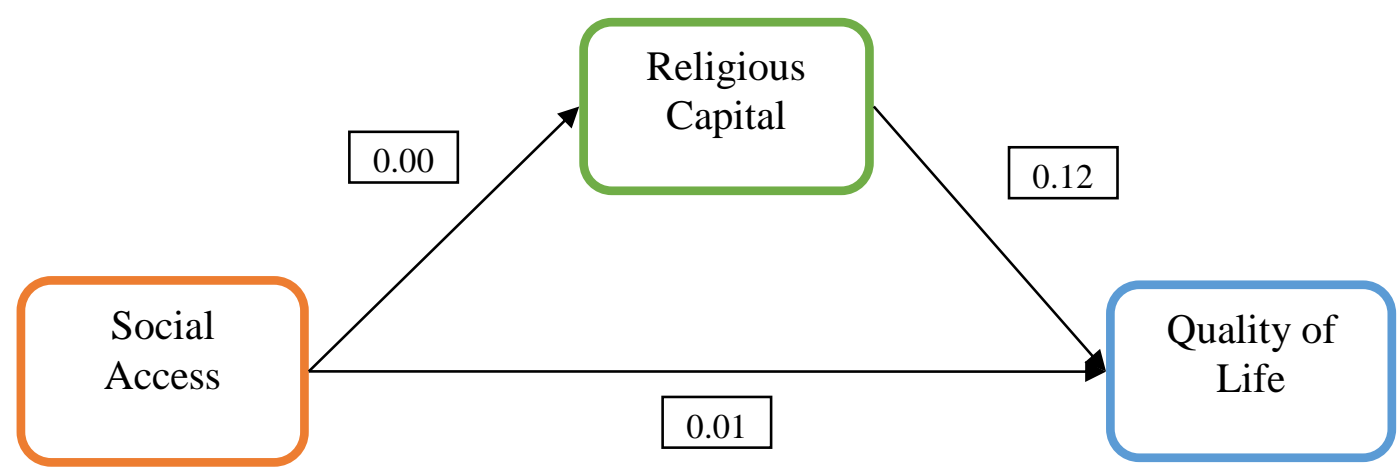

Graph 4. Multiregression Analysis Indonesia

Source: own data

Multi regression analysis between social access, religious capital, and quality of life in Indonesia has indicated that there is a stronger effect of religious capital towards quality of life in Indonesia compared to Thailand. In the province of Banten, especially in Pandeglang, where the dominant religion is Islam, religious capital has a direct relation with quality of life. A relatively similar phenomenon is also the case for the province of Bali where the dominant religion is Hinduism. In Bali, religious capital has a direct relation with quality of life. Meanwhile, in the province of Yogyakarta, the religious capital has less strong effect compared with the effect of social access, although Muslims are the majority of population.

On the other hand, there is a weak effect of social access towards religious capital in Indonesia. Although based on the qualitative data, in Bali social access does affect religious capital, but it is not the case for Pandeglang and Serang, Banten, as well as for Yogyakarta. In Banten and Yogyakarta, social access does not have a strong effect on religious capital.

There is also a weak effect of social access towards quality of life in Indonesia. The qualitative data gathered in Pandeglang and Serang, Banten, as well as in Denpasar, Bali, has shown that religious capital has stronger effect on quality of life compared with the effect of social access. It is clearly shown in Banten where Islam is the dominant religion held by the majority and in Bali where the dominant religion is Hinduism. The more dominant a certain religion, the higher is the religious capital of its adherents, and the higher the religious capital's effect on the quality of life compared with the effect of social access. However, in Yogyakarta, the social access has a slightly stronger effect towards quality of life compared to Banten and Bali. But, overall, it can be concluded that the quality of life in Indonesia is more affected by religious capital than by social access. In the other words, in Indonesia religious capital is more important than social access in affecting quality of life.

Data above represents the strengthening of religious identity and orientation (as a part of religious capital) influences the social relations among the members of community with different religious backgrounds. Boundaries of religious identity mark the identification that distinguishes between 'us' among those who have similar religious background and 'them' that is those who have other religious backgrounds. It means religious identity, in turn, presents as a social capital that contributes to individual's life.

In heterogeneous society like Indonesia, religious capital plays important roles in public domain, because of its use as the basis for access to resources. Trust and networking developed in community contribute to individuals' subjective meaning concerning their life satisfaction 
and happiness. It means that the findings demonstrate significant influence of religious capital on the relation between social access and quality of life.

\subsubsection{Thailand Social Access, Religious Capital, Quality of Life: Multiregression Analysis}

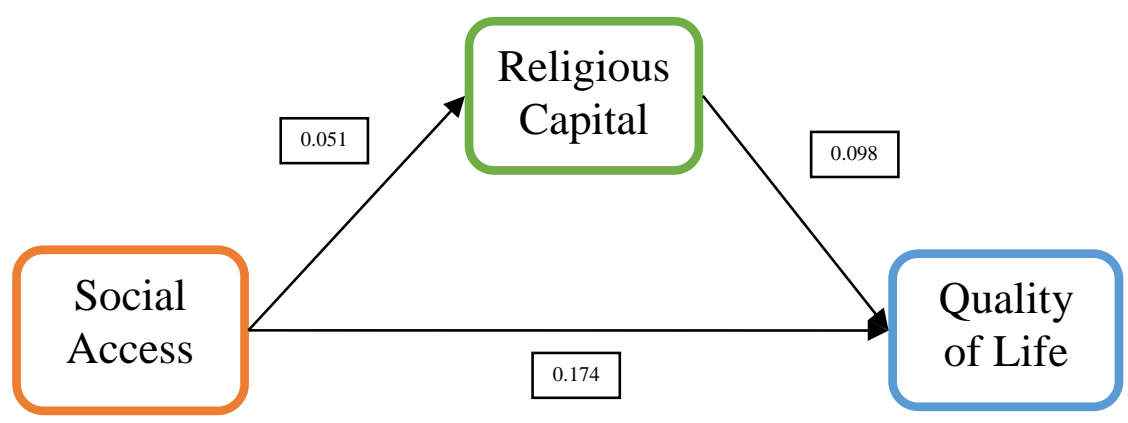

Graph 5. Multiregression Analysis Thailand

Source: own data

In Thailand, the multiregression analysis shows that there is a stronger effect of social access towards quality of life compared to Indonesia. There is a weak effect of social access towards religious capital in Thailand. There is also a weak effect of religious capital towards quality of life in Thailand. Thus, social access has a stronger effect on quality of life than religious capital. It is evident based on secondary data analysis, that in Thailand religious capital has less effect on quality of life compared to social access.

It is interesting to note that even though both Thailand and Indonesia has one dominant religion in particular, i.e. Buddhism in Thailand and Islam in Indonesia, only in Indonesia religious capital has more effect on quality of life. In Thailand, social access has more effect on quality of life compared with religious capital. Thus, the dominance of one specific religion in a particular country does not automatically imply that religious capital has more effect on the quality of life compared with social access.

Referring to literatures on social capital and religion, many occur in countries without a dominant religion, either as an identity or a basis for social interaction. On the other hand, the conditions in Thailand show that social interaction in achieving quality of life is not too influenced by their religious identity, but is more influenced by other factors such as the effectiveness of public services by the government as a structural aspect, and social capital in general in the community, which is not based religious identity. The color of Buddhism, which is more interpreted as the way of life in Thailand and less dominant as an identity, is also a differentiator in Thailand. Therefore, relations within the community and with the government in the context of public services are not too influenced by religious capital.

Survey data in Thailand also shows that quality of life is largely influenced by factors such as work, place of residence, social class. Besides that, what is interesting is the influence of the role of the government on the higher quality of life in Thailand compared to Indonesia. This indicates that structural factors are more dominant in explaining the quality of life variable in Thailand, while in Indonesia cultural factors such as identity and religious capital in interactions, ethnic identity, are quite dominant in influencing the quality of life conditions. 


\section{Conclusion}

The relation between Social Access, Religious Capital, and Quality of Life in Thailand and in Indonesia are interestingly different. Even though both Indonesia and Thailand has one dominant religion practiced by the vast majority of their population, the relation is quite different. In Thailand, social access has more effect on quality of life. In Indonesia, on the other hand, religious capital has more effect on quality of life compared with social access. In heterogeneous society, religious capital plays important roles in public domain, because of its use as the basis for access to resources. Trust and networking developed in community contribute to individuals' subjective meaning concerning their life satisfaction and happiness. Religious capital with its three dimensions as "religious identity, religious orientation and activities that exercised in social relations and contribute to the growing of social solidarity and trust among community members. Religious capital means a lot as significant social factors for social access, and positively demonstrate significant influence on the relation between social access and quality of life.

Based on the SWB survey, average score of religious capital in Indonesia is 7.3, compared to Thailand with 5.8. Thus, Indonesian respondents vie religious capital as more significant factor in their lives compared to respondents in Thailand.

The qualitative primary data in Indonesia, specifically in Bali, Yogyakarta, and Banten provinces also indicate that there are differences on how strong religious capital has effect on quality of life. This is indicated by the research results, where in the province of Banten with islam as its dominant religion and Bali with hindu as its dominant religion, religious capital has a direct relation with quality of life. In Yogyakarta, religious capital has less strong effect compared with the effect of social access though islam is the majority but with less dominant influence. Unfortunately, for Thailand, there is no qualitative data available. Further detailed research is needed to have more comprehensive and holistic data on both Thailand and Indonesia.

\section{Acknowledgement}

This study initiated by the International Consortium for Social Well-being Studies, led by Senshu University Japan. In Indonesia, this collaboration was funded by LabSosio Universitas Indonesia as mestioned in contract letter no: 80/PT.02.05/LS-FISIP-UI/VII/2017. 


\section{References}

Berger, P \& Hefner, R. (2003). Spiritual Capital in Comparative Perspective. Paper prepared for the Spiritual Capital Planning Meeting 2003

Boon, B \& Farnsworth, J. (2011). Social Exclusion and Poverty: Translating Social Capital into Accessible Resources. Social Policy \& Administration, 45(5), 507-524. DOI: 10.1111/j.1467-9515.2011. 00792.x

Bowman, N., Denson, N \& Park, J. (2015). Racial/Cultural Awareness Workshops and PostCollege Civic Engagement: A Propensity Score Matching Approach. American Educational Research Journal, 53(6), 1556-587. DOI: org/10.3102/0002831216670510

Bucur, A. (2017) How can we apply the models of the quality of life and the quality of life management in an economy based on knowledge?. Economic Research-Ekonomska Istraživanja, 30(1), 629-646, DOI: 10.1080/1331677X.2017.1314821

Candland, C. (2000). Faith as Social Capital: Religion and Community Development in Southern Asia. Policy Sciences, 33, 355-374. DOI: org/10.1023/A:1004857811117

Guillen-Royo, M., Velazco, J., \& Camfield, L. (2011). Basic Needs and Wealth as Independent Determinants of Happiness: An Illustration from Thailand. Social Indicators Research, 110, 517-536. DOI: $10.1007 / \mathrm{s} 11205-011-9941-3$

Haq, R \& Zia, U. (2013). Multidimensional Wellbeing: An Index of Quality of Life in a Developing Economy. Social Indicators Research, 114, 997-1012. DOI.org/10.1007/s11205-012-0186-6

Hefner, R. (2015). Review of Faith and the State: A History of Islamic Philanthropy in Indonesia, Brill, Leiden and Boston, South East Asia Research, DOI: 10.5367/sear.2015.0262

Helliwell, J., Layard, R \& Sachs, J (2017). World Happiness Report 2017. Sustainable Development Solutions Network

Hoon, C. (2016). Religious aspirationsamong urban Christians in Contemporary Indonesia. International Sociology, 31(4), 413-431. DOI:10.1177/0268580916643853

Human Development Index Report 2016, UNDP.

Indonesia Statistical Bureau. (2011). Kewarganegaraan, Suku Bangsa, Agama, dan Bahasa Sehari-hari Penduduk Indonesia, Hasil Sensus Penduduk 2010, Jakarta: BPS.

Jaskiewicz, M., \& Besta, T. (2016). Is easy access related to better life? Walkability and overlapping of personal and communal identity as predictors of quality of life. Applied Research Quality Life, 9, 505-516. doi:10.1007/s11482-013-9246-6

Kireenko, A., \& Nevzorova, E. (2015). Impact of Shadow Economy on Quality of Life: Indicators and Model Selection. Procedia Economic and Finance, 25, 559-568. DOI:10.1016/S2212-5671(15)00770-4

Koo, H., Yee, J., Yeong Nam, E., \& Sun Kim, E. (2016). Dimensions of Social Well-being and Determinants in Korea: Personal, Relational, and Societal Aspects. The Senshu Social Well-being Review, 3, 37-58. www.researchgate.net/publication/328802141

Lee, J., \& Shrum, L. (2012). Conspicuous Consumption versus Charitable Behavior in Response to Social Exclusion: A Differential Needs Explanation. Journal of Consumer Research, 39(3), 530-544. DOI:10.1086/664039

Peace, R. (2001). Social Exclusion in Need of Definition. Social Policy Journal of New Zealand. 16(16), 17-35. DOI:10.1.1.627.6786

PS Goh, D., \& Van Der Veer, P. (2016). Introduction: The sacred and the urban in Asia. International Sociology, 31(4), 367-374. doi:10.1177/0268580916643088

Putnam, Robert. (2000). Bowling Alone: The Collapse and Revival of American Community. New York: Simon and Schuster. 
Roemer, M. K. (2010). Religion and Subjective Well-being in Japan. Review of Religious Research, 51(4), 411-427. DOI:10.2307/20778532

Van der Veer, P. (2009). Spirituality in Modern Society, Germany: MPI.

Zhang, K., Hui, C., Lam, J., Lau, E., Cheung, S., \& Mok, D. (2013). Personal Spiritual Values and Quality of Life: Evidence from Chinese College Students. Journal of Religion and Heatlh, 53, 986-1002. DOI:10.1007/s10943-013-9686-1 


\section{Attachment}

Social exclusion (trust, participation, access)

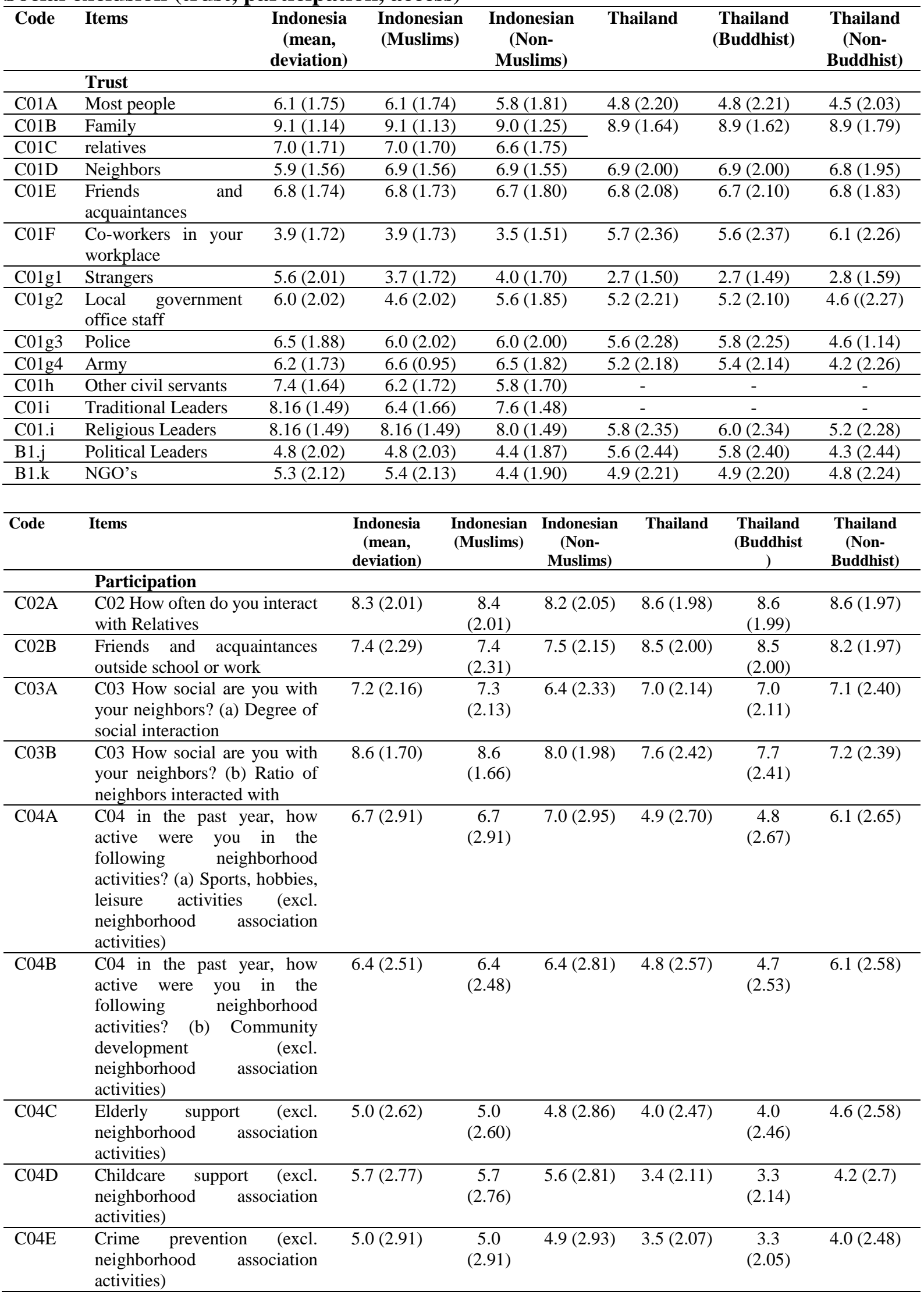


RECENT ISSUES IN SOCIOLOGICAL RESEARCH

\begin{tabular}{|c|c|c|c|c|c|c|c|c|}
\hline $\mathrm{C} 04 \mathrm{~F}$ & \multicolumn{2}{|c|}{$\begin{array}{l}\text { Disaster prevention (excl. } \\
\text { neighborhood association }\end{array}$} & $4.4(2.49)$ & $\begin{array}{c}4.4 \\
(2.47)\end{array}$ & $4.3(2.65)$ & $5.8(2.55)$ & $\begin{array}{c}3.3 \\
(1.98)\end{array}$ & $4.6(2.40)$ \\
\hline $\mathrm{C04G}$ & $\begin{array}{l}\text { Neighborhood assoc } \\
\text { activities (incl. meeting }\end{array}$ & ation's & $7.0(2.50)$ & $\begin{array}{c}7.0 \\
(2.47) \\
\end{array}$ & $6.4(2.80)$ & $5.4(2.02)$ & $\begin{array}{c}5.8 \\
(2.57) \\
\end{array}$ & $6.0(2.46)$ \\
\hline $\mathrm{C} 05$ & $\begin{array}{l}\text { C05 How involved are } \\
\text { traditional festivals } \\
\text { area in which many } \\
\text { members of your con } \\
\text { participate? }\end{array}$ & $\begin{array}{r}\text { you in } \\
\text { your } \\
\text { other } \\
\text { munity }\end{array}$ & $7.8(2.08)$ & $\begin{array}{c}7.8 \\
(2.05)\end{array}$ & $7.7(2.38)$ & $7.3(2.50)$ & $\begin{array}{c}7.3 \\
(2.54)\end{array}$ & $7.0(2.19)$ \\
\hline \multirow[t]{2}{*}{ Code } & $\begin{array}{c}\text { Items (Semakin } \\
\text { Tinggi Semakin } \\
\text { Baik Akses } \\
\text { tersebut) }\end{array}$ & $\begin{array}{l}\text { Indonesia } \\
\text { (mean, } \\
\text { deviation) }\end{array}$ & $\begin{array}{c}\text { Indonesian } \\
\text { (Muslims) }\end{array}$ & $\begin{array}{r}\text { Ind } \\
\text { Mu }\end{array}$ & $\begin{array}{l}\text { esian } \\
\text { n- } \\
\text { ms) }\end{array}$ & Thailand & $\begin{array}{l}\text { Thailand } \\
\text { (Buddhist) }\end{array}$ & $\begin{array}{l}\text { Thailand } \\
\text { (Non- } \\
\text { Buddhist) }\end{array}$ \\
\hline & $\begin{array}{l}\text { Access: people are } \\
\text { treated fairly based } \\
\text { on the following } \\
\text { attributes in current } \\
\text { Indonesian society as } \\
\text { a whole? }\end{array}$ & & & & & & & \\
\hline W03a & Gender & $6.6(2.47)$ & $6.7(2.44)$ & 6.4 & $2.81)$ & $3.4(2.19)$ & $3.4(2.21)$ & $4.0(1.94)$ \\
\hline W03b & Age & $6.7(2.45)$ & $6.7(2.41)$ & 6.5 & $2.78)$ & $3.6(2.04)$ & $3.5(2.07)$ & $4.0(1.79)$ \\
\hline W03c & $\begin{array}{l}\text { Educational } \\
\text { background }\end{array}$ & $6.2(2.58)$ & $6.2(2.56)$ & & $2.84)$ & $3.7(2.21)$ & $3.7(2.24)$ & $3.8(1.89)$ \\
\hline W03d & Occupation & $5.9(2.60)$ & $5.9(2.57)$ & 5.8 & $2.89)$ & $3.9(2.16)$ & $3.9(2.17)$ & $4.0(2.07)$ \\
\hline W03e & Income & $5.8(2.61)$ & $5.8(2.57)$ & 5.5 & 2.95) & $4.2(2.23)$ & $4.2(2.25)$ & $4.6(2.08)$ \\
\hline W03f & Assets & $5.7(2.56)$ & $5.8(2.52)$ & 5.6 & $2.90)$ & $4.2(2.29)$ & $4.1(2.29)$ & $4.9(2.12)$ \\
\hline W03g & Family background & $6.1(2.65)$ & $6.1(2.61)$ & 6.1 & $3.04)$ & $3.1(2.41)$ & $3.0(2.43)$ & $3.8(2.10)$ \\
\hline W03h1 & Race & $6.4(2.68)$ & $6.4(2.62)$ & & $3.19)$ & $2.5(2.39)$ & $2.4(2.37)$ & $3.8(2.19)$ \\
\hline W03h2 & Ethnicity & $6.7(2.57)$ & $6.7(2.5)$ & & $3.13)$ & & & \\
\hline W03k1 & Religion & $7.3(2.53)$ & $7.4(2.45)$ & 6.3 & $3.09)$ & $1.9(2.11)$ & $1.8(2.06)$ & $2.9(2.34)$ \\
\hline W03k2 & Traditional Beliefs & $7.0(2.50)$ & $7.0(2.44)$ & & 2.99) & - & - & - \\
\hline
\end{tabular}


RECENT ISSUES IN SOCIOLOGICAL RESEARCH

Quality of life (general)

\begin{tabular}{|c|c|c|c|}
\hline Code & Items & $\begin{array}{c}\text { Indonesia (mean, } \\
\text { deviation) }\end{array}$ & $\begin{array}{c}\text { Thailand (mean, } \\
\text { deviation) }\end{array}$ \\
\hline & Personal & $8.03(1.50)$ & $7.6(1.80)$ \\
\hline \multirow[t]{2}{*}{ W02A } & $\begin{array}{l}\text { W02 How satisfied are you currently with the } \\
\text { following (a) Current life overall }\end{array}$ & $8.03(1.50)$ & $7.6(1.80)$ \\
\hline & Relational & $6.9(0.98)$ & $6.1(1.29)$ \\
\hline $\begin{array}{l}\text { C01a- } \\
\text { C01f }\end{array}$ & Perception (Trust) & $6.6(6.67)$ & $7.9(1.50)$ \\
\hline $\begin{array}{l}\mathrm{C} 02 \mathrm{a}- \\
\mathrm{C} 03 \mathrm{~b}\end{array}$ & Interaction (Face to Face Contact) & $7.9(1.25)$ & $4.9(1.8)$ \\
\hline $\mathrm{C} 04 \mathrm{a}-\mathrm{C} 05$ & Participation (In Community) & $6.2(1.76)$ & $6.3(1.04)$ \\
\hline & Societal & $6.8(1.30)$ & $7.1(1.37)$ \\
\hline W05b & $\begin{array}{l}\text { W5. How do you agree to the following } \\
\text { statements on the current Indonesian society? } \\
\text { B. Opportunities for university education are } \\
\text { equally available to all regardless of wealth } \\
\text { disparity }\end{array}$ & $7.8(1.94)$ & $7.4(2.6)$ \\
\hline W05c & $\begin{array}{l}\text { W5. How do you agree to the following } \\
\text { statements on the current Indonesian society? } \\
\text { C. The disabled can be socially active, } \\
\text { regardless of their degree of disability }\end{array}$ & $7.5(1.86)$ & $8.03(2.21)$ \\
\hline W05d & $\begin{array}{l}\text { W5. How do you agree to the following } \\
\text { statements on the current Indonesia society? } \\
\text { D. There is an equal distribution of income } \\
\text { (W05d, reversed) }\end{array}$ & $3.2(2.2)$ & $7.9(2.04)$ \\
\hline W05e & $\begin{array}{l}\text { e. The difference of income will be stable for } \\
\text { the next } 10 \text { years (w05e, reversed) }\end{array}$ & $3.2(2.3)$ & $7.6(2.15)$ \\
\hline $\begin{array}{l}\text { C01g1- } \\
\text { c01g4 }\end{array}$ & $\begin{array}{l}\text { C1. To what degree do you feel you can trust } \\
\text { or not trust the following people? G. Local } \\
\text { Government Office (Staff, Police, Army, and } \\
\text { other Civil Servants) }\end{array}$ & $6.1(1.62)$ & $5.0(4.80)$ \\
\hline & OVERALL QUALITY OF LIFE & $7.2(0.87)$ & $7.0(0.97)$ \\
\hline
\end{tabular}


RECENT ISSUES IN SOCIOLOGICAL RESEARCH

Quality of life based on religion (Indonesia \& Thailand)

\begin{tabular}{|c|c|c|c|c|c|}
\hline Code & Items & $\begin{array}{l}\text { Indonesia } \\
\text { (Muslim) }\end{array}$ & $\begin{array}{l}\text { Indonesia } \\
\text { (Non- } \\
\text { Muslim) } \\
\end{array}$ & $\begin{array}{l}\text { Thailand } \\
\text { (Buddhist) }\end{array}$ & $\begin{array}{l}\text { Thailand } \\
\text { (Non- } \\
\text { Buddhist) }\end{array}$ \\
\hline & Personal & $8.04(1.48)$ & $8.0(1.68)$ & $7.6(1.82)$ & $7.5(1.54)$ \\
\hline W02A & $\begin{array}{l}\text { W02 How satisfied are you currently with } \\
\text { the following (a) Current life overall }\end{array}$ & $8.04(1.48)$ & $8.0(1.68)$ & $7.6(1.82)$ & $7.5(1.54)$ \\
\hline & Relational & $6.9(0.98)$ & $6.7(1.11)$ & $6.3(1.04)$ & $5.4(1.85)$ \\
\hline $\begin{array}{l}\text { C01a- } \\
\text { C01f }\end{array}$ & Perception (Trust) & $6.8(1.06)$ & $6.5(1.09)$ & $6.1(1.30)$ & $7.1(2.00)$ \\
\hline $\begin{array}{l}\mathrm{C} 02 \mathrm{a}- \\
\mathrm{C} 03 \mathrm{~b}\end{array}$ & Interaction (Face to Face Contact) & $7.9(1.25)$ & $7.6(1.28)$ & $7.9(1.50)$ & $6.1(1.21)$ \\
\hline $\begin{array}{l}\text { C04a- } \\
\mathrm{C} 05\end{array}$ & Participation (In the Community) & $6.2(1.79)$ & $5.9(2.05)$ & $4.8(1.81)$ & $7.9(1.53)$ \\
\hline & Societal & $6.7(1.30)$ & $7.1(1.37)$ & $5.1(1.12)$ & $4.7(1.04)$ \\
\hline W05b & $\begin{array}{l}\text { B. Opportunities for university education } \\
\text { are equally available to all regardless of } \\
\text { wealth disparity }\end{array}$ & $7.8(1.94)$ & $8.0(1.91)$ & $7.4(2.60)$ & $7.0(2.20)$ \\
\hline W05c & $\begin{array}{l}\text { C. The disabled can be socially active, } \\
\text { regardless of their degree of disability }\end{array}$ & 7.5 (1.85) & $7.6(2.00)$ & $8.1(2.18)$ & $7.1(2.22)$ \\
\hline W05d & $\begin{array}{l}\text { D. There is an equal distribution of } \\
\text { income (W05d, reversed) }\end{array}$ & $3.2(2.2)$ & $2.6(1.88)$ & $2.1(2.05)$ & $2.3(1.91)$ \\
\hline W05e & $\begin{array}{l}\text { e. The difference of income will be stable } \\
\text { for the next } 10 \text { years (w05e, reversed) }\end{array}$ & $3.2(2.4)$ & $2.5(2.06)$ & $2.4(2.16)$ & $2.7(2.07)$ \\
\hline $\begin{array}{l}\text { C01g1- } \\
\text { c01g4 }\end{array}$ & $\begin{array}{l}\text { C1. To what degree do you feel you can } \\
\text { trust or not trust the following people: } \\
\text { Local Government Office (Staff, Police, } \\
\text { Army, and other Civil Servants) }\end{array}$ & $6.1(1.63)$ & $6.0(1.57)$ & $5.1(1.78)$ & $4.3(1.84)$ \\
\hline & OVERALL QUALITY OF LIFE & $7.2(0.87)$ & $7.0(0.97)$ & $6.3(0.90)$ & $6.3(0.77)$ \\
\hline
\end{tabular}

Religious capital

\begin{tabular}{|c|c|c|c|}
\hline Code & Common Items & $\begin{array}{c}\text { Indonesia (mean, } \\
\text { deviation) }\end{array}$ & $\begin{array}{c}\text { Thailand (mean, } \\
\text { deviation) }\end{array}$ \\
\hline W3K1 & $\begin{array}{l}\text { W03 How do you think people are treated } \\
\text { unfairly based on the following attributes in } \\
\text { current Indonesian society as a whole? (k1) } \\
\text { Religion (reversed) }\end{array}$ & $7.3(2.53)$ & $1.9(2.11)$ \\
\hline W4K1 & $\begin{array}{l}\text { W04 How do you think the following attributes } \\
\text { or attainments of yourself have given you an } \\
\text { advantage or a disadvantage in your life so far? } \\
\text { (k) Religion }\end{array}$ & $7.5(1.96)$ & $7.4(2.20)$ \\
\hline $\mathrm{C} 1 \mathrm{i} ; \mathrm{C} 01 \mathrm{~m}$ & $\begin{array}{l}\text { C01 To what degree do you feel you can trust } \\
\text { or not trust the following people? (i) religious } \\
\text { leader }\end{array}$ & $8.2(1.50)$ & $5.8(2.35)$ \\
\hline $\mathrm{C} 07$ & $\begin{array}{l}\text { C07 How frequently do you attend memorials } \\
\text { or services for those close to you or ancestors } \\
\text { who have already died? Ritual }\end{array}$ & $6.0(4.61)$ & $4.9(1.74)$ \\
\hline R02i & $\begin{array}{l}\text { R02 What people or organizations do you rely } \\
\text { upon to help you deal with your personal daily } \\
\text { problems and concerns(i) Temple, church or } \\
\text { other religious group }\end{array}$ & $7.2(2.12)$ & $5.3(2.49)$ \\
\hline \multirow[t]{2}{*}{ R06i } & $\begin{array}{l}\text { R06 Which people or groups would you rely } \\
\text { upon if a large natural disaster or accident } \\
\text { occurred in your residential area? (i) Temple, } \\
\text { church or other religious group }\end{array}$ & $7.8(1.78)$ & $5.6(2.47)$ \\
\hline & OVERALL RELIGIOUS CAPITAL & $6.6(1.20)$ & $5.2(1.11)$ \\
\hline
\end{tabular}

